\title{
Integrating Perceived Added Educational Value Business Administration Core Course Items into Scales and Their Relationships to Degree Program Satisfaction and Business School Reputation Influence
}

\author{
Gary Blau ${ }^{1}$ \\ ${ }^{1}$ Temple University, Philadelphia, PA, USA \\ Correspondence: Gary Blau, Human Resource Management Dept., Fox School of Business \& Management, \\ Alter Hal \#349 (006-00) - 1801 Liacouras Walk, Temple University, Philadelphia, PA 19122, USA. E-mail: \\ gblau@temple.edu
}

Received: April 13, 2019 Accepted: May 8, $2019 \quad$ Online Published: June 13, 2019

doi:10.5539/jel.v8n4p1 URL: https://doi.org/10.5539/jel.v8n4p1

\begin{abstract}
Prior research has not investigated perceived added education value in courses. Using a sample of 165 graduating business students, two business administration (BA) scales were created from six required BA core courses as part of students' Bachelor of Business Administration (BBA) degree. Students were asked if each required course "added value to their education". The two core scales (number of items) were labeled: BA Unique (4 items) and BA Generic (2 items). Analysis showed that the BA Unique scale had higher perceived added education value than the BA Generic scale. The BA Unique scale had stronger relationships to program degree satisfaction and Business School reputation than the BA Generic scale. These results supported the development of more unique required core courses based on business school stakeholder needs. Other schools should consider their stakeholders' needs to see if more unique required core courses, beyond generic, are needed. Although only six of 21 required courses could be tested due to sample size limitations, these initial results suggest it is important to evaluate the perceived added education value of required courses in a curriculum.
\end{abstract}

Keywords: added education value, business core courses, business core scales, program degree satisfaction

\section{Introduction}

\subsection{Introduce the Problem}

With increasing college costs, one important priority is trying to ensure that students are satisfied with their college education (National Student Satisfaction and Priorities Report, 2017). Gathering the student's perspective is important, and the overall perceived value of education has been positively linked to general student satisfaction across multiple studies (Alves, 2011; Ledden, Kalafatis, \& Samouel, 2007). Typical business college degree programs in the United States include required core courses, which all business students must take, regardless of their subsequent major (Martell, 2007). The purpose of this study was to measure business student perceived added education value of six required business administration core courses, to then test if a smaller number of business core scales could be successfully created. The relationships between these created scales and their subsequent relationships to business students' program degree satisfaction and business school reputation were then tested. Prior relevant literature is reviewed below.

\subsection{Relevant Scholarship - Business Core Curriculum}

Prior research has noted the need for business schools to create a business core curriculum to adequately prepare undergraduates for more specialized study in their major (Meade, 1986; Pharr, 2000). For many business schools, the business core curriculum must also meet the standards of the Association to Advance Collegiate Schools of Business (AACSB), including providing a common body of business knowledge (Pharr, 2000). More recently, the AACSB (AACSB, 2013, p. 34) has provided an updated list of required skill areas, including general skill (e.g., written and oral communication), technological agility (e.g., application of statistical tools), and general business knowledge. Within general business knowledge (p. 34) are included (1) "economic, political, regulatory, 
legal, technological, and social contexts of organizations in a global society" and (2) "social responsibility, including sustainability, diversity and ethical behavior and approaches to management." Across many business schools, including AASCB-accredited, these courses are often labeled: (1) "Business Policy, Business Strategy and Policy, Strategic Management" or something similar (Payne, Whitfield, \& Flynn, 2002); and (2) "Business Ethics, Business Society and Ethics" or something similar (Nelson, Smith, \& Hunt, 2014).

All undergraduate business students, regardless of their major, would receive these required learning experiences via the business core. Prior research has studied different variables in relationship to the business core curriculum, for example: faculty, administrator and student attitudes towards a business core curriculum (Pharr, 2003); the relationships of student teaching evaluations to business core courses (Yunker \& Yunker, 2003); and the impact of business core course reviews on student comprehensive business examination scores (Hahn, 2018). However, no prior research was found asking for student perceptions of the "added value to their education" for individual business core courses. This perception is different from asking for student teaching evaluations of a course.

Student teaching course evaluations tend to focus more on the instructor (e.g., knowledge of subject, organized class sessions, fair grading, genuine interest in teaching), then on a course adding educational value (Peterson, Berenson, Misra, \& Radosevich, 2008). In addition, often multiple sections of a business core course, taught by different instructors, are needed to meet student demand. Standardizing the core course content across these different sections is needed to give students a common body of knowledge. It is necessary, within a business school and the affected department, to examine the perceived student added educational value of a particular business core course (e.g., to revise/improve the course curriculum). However, from a general research perspective, it becomes inefficient to work with core courses as individual items. For example, multicollinearity (Stevens, 1996) or overlap between individual course items would make it more difficult to separate out the distinct relationships of individual core course items with other variables. By collapsing overlapping course items into a smaller set of distinct scales, it should be easier to separate out any differential relationships with other variables. As part of their required business core in the business school at this research setting, undergraduates are required to take six business administration core courses. Thus, the first research question (RQ) to be tested was:

$R Q 1$ - are there distinct added education value business administration core scales that are valid, reliable and sufficiently independent from one another?

A second research question to test would be, assuming distinct scales, are they perceived by students as equal in added education value? This suggests:

$R Q 2$ - if there are distinct added education value business administration core scales, are they perceived as equal in added education value (i.e., no difference in scale means)?

\subsection{Satisfaction with Degree Program and Perceived Business School Reputation Influence}

Research (e.g., Davidson, Beck, \& Milligan, 2009) has demonstrated that college students' satisfaction positively affected their retention or persistence towards graduating. Prior work measuring college student satisfaction has often used measures that are either too long, for example the 116-item Student Satisfaction Inventory (SSI, 2018) or too short, for example a one-item measure (Pelletier et al., 2017). Given the prior-acknowledged business core as separate from courses within one's major (Martell, 2007), this suggests that a short multi-item approach to measuring student degree program satisfaction (i.e., BBA satisfaction, where BBA is Bachelor of Business Administration) would be valid. Blau, Williams, Jarrell and Nash (2019) recently found support for using a three-item BBA satisfaction scale, which aggregated measuring satisfaction with the overall program, major courses, and core courses. Prior research has shown perceived overall value of education to be positively related to general student satisfaction (Alves, 2011). However, the relationship of added education value business core scales to BBA satisfaction has not yet been tested. If BBA satisfaction can affect student persistence towards their degree, understanding the correlates of such satisfaction is important.

A business school's reputation can be important to study (Vidaver-Cohen, 2007). Blau, Halbert, Atwater, Kershner and Zuckerman (2016) found that a one-item measure of business school reputation influencing student's perceived market value to potential employers (business school reputation influence) had a positive relationship to a one-item measure of program degree satisfaction. However, there has been no prior research testing the relationships of added education value business administration core scales to business school reputation influence. This leads to the third research question:

$R Q 3$ - is there a difference in the relationships of the added education value business administration core scales 
to BBA satisfaction and business school reputation influence?

\section{Method}

\subsection{Sample and Procedure}

The sample consisted of undergraduate business students graduating at the end of the fall 2018 semester. The business school research site is part of a large urban state-supported university (University X) located in the Mid-Atlantic region of the United States. The most recent enrollment data noted that this business school had approximately $24 \%$ of the total undergraduate enrollment $(6,856 / 28,767)$. Near the end of the 14 -week semester all graduating seniors were strongly encouraged (by their advisor and through email blasts) to complete a voluntary online Senior Student Satisfaction Survey (SSSS) prior to graduation. All study measures were part of the SSSS. All data were stored in a Qualtrics data base. One hundred and seventy-six graduating seniors responded by filling out the SSSS. This represented approximately $50 \%$ of the Fall 2018 graduating business senior class. The university institutional review board (IRB) approved the research as part of a general program review. Ninety-three percent of the sample were full-time students (taking at least 12 credits/semester); $54 \%$ were male and $74 \%$ of the sample had lived for at least one semester on or near the University X main campus.

\subsection{Measures}

Business Administration Core Courses. The business school is quite large and offers sixteen different majors taught by over 200 full-time faculty and many adjuncts. Of the 21 required business core courses, six are in the business administration (BA) area. For these six core courses, it is much harder to waive any of these courses, for example if joining the business school as a transfer student. Two of the six offered BA courses are much more common across AACSB business schools, a business ethics course and a capstone business policy course (AACSB, 2013; Nelson et al., 2014; Payne et al., 2002). In the business school research setting these are called (course number) "Business Society and Ethics" (BA 3102), and "Global Business Policies" (BA 4101). Both of these courses are each three credits.

There are four more unique BA core courses not typically found across AACSB business schools. These courses were developed based on student, faculty, employer and other stakeholder needs. These four courses in the business school research setting are called: "Professional Development Strategies" (BA 2101), "Excel for Business Applications" (BA2104), "Business Communications (BA 2196), and "Integrative Business Applications" (BA 3103). BA 2101 and BA 2104 are one-credit courses, while BA 2196 and BA 3103 are each three-credit courses. These courses were based on more unique business school factors, such as its larger size, which allows the business school to have its own career center. The business school career center staffs BA 2101. The emphasis on Excel across business courses necessitated the development of BA 2104. The BA 2196 course is a writing-intensive course focused on helping students develop their oral, written, and analytical skills. It is limited to 20 students/section to allow for more intensive communication learning and application. Finally, the BA 3103 course requires students to use specific business simulation software to test alternative ways to operate a business in a competitive environment. BA 3103 integrates much of the business core outside of business administration (e.g., finance, management information systems, management science and operations management, risk management and insurance). It helps to prepare them for the Global Business Policies course (BA 4101).

Collectively, these six BA core courses help to address the general skill, general business knowledge and technological agility areas noted by the AACSB (AACSB, 2013, p. 9). These six courses also collectively address the four general learning goals of the business school: (1) demonstrate business knowledge needed to make business decisions; (2) apply critical thinking to business problems; (3) apply quantitative reasoning skills to make recommendations and business decisions; and (4) apply effective business communication techniques to business situations. The survey lead-in for these six core course items was, "the following business core course added value to my education." There were six-response options for each item, where $1=$ strongly disagree, $2=$ disagree, 3 = slightly disagree, $4=$ slightly agree, $5=$ agree, and $6=$ strongly agree. A seventh response option was "not applicable," to be checked if a student either took the equivalent course at another accredited business school or waived out of a particular core course. These "not applicable" responses were coded as missing data.

BBA Satisfaction. The three-item measure noted earlier was used in this study. The three items were: "overall I am satisfied with the business core requirements", "overall I am satisfied with my major", and "overall I am satisfied with the BBA program." Items were answered using a $1=$ strongly disagree to $6=$ strongly agree response scale. Prior research (Blau et al., 2019) found reliabilities of .86 and .85 with separate samples.

Business School Reputation Influence was measured by asking respondents to indicate their level of agreement with the statement "the reputation of the Business School influences your market value to potential employers," 
using a six-point response scale, where $1=$ strongly disagree to $6=$ strongly agree.

\subsection{Data Analyses.}

All data were analyzed using SPSS (2015). Assuming a distinction between business administration core "unique" versus generic" individual courses, two scales were formed and tested (unique versus generic) to see if adequate scale reliabilities could be found, and the correlation between the two scales allowed them to remain distinct. These were the analyses for RQ1. Assuming two distinct scales, to test the second RQ, a paired sample t-test was calculated to determine if the two-business administration core scale means were significantly different from each other. To test RQ3, correlations between the two business administration core scales to BBA satisfaction and business school reputation influence were tested for significant differences. Two-tailed tests were done for all analyses. When the data for all variables were combined for scale formation there were 11 missing cases out of the $176(6 \%)$, so the sample size became $\mathrm{N}=165$,

\section{Results}

\subsection{General Results for Six Business Administration Core Course Items}

Table 1 presents the means, standard deviations and missing data for the six-business administration core course items working with the full initial sample size $(\mathrm{N}=176)$. The lowest perceived added educational value course was \#5, BA 3103, Integrative Business Applications, $M=4.12$, and the highest was \#3, BA 2196, Business Communications, $M=5.02$. There is minimal missing data.

Table 1. Six bachelor of business administration (BBA) core course item means (M), standard deviations (SD) and missing cases

\begin{tabular}{llll}
\hline Course and Title $^{\mathrm{a}}$ & Mean $^{\mathrm{b}}$ & SD & Missing \\
\hline 1. BA 2101-Professional Development Strategies & 4.54 & 1.45 & 2 \\
2. BA 2104-Excel for Business Applications & 4.56 & 1.46 & 8 \\
3. BA 2196-Business Communications & 5.02 & 1.16 & 1 \\
4. BA 3102-Business, Society and Ethics & 4.28 & 1.48 & 3 \\
5. BA 3103-Integrative Business Applications & 4.12 & 1.57 & 0 \\
6. BA 4101-Global Business Policies & 4.59 & 1.48 & 0 \\
\hline
\end{tabular}

Note. $\mathrm{N}=176$.

${ }^{\mathrm{a}} \mathrm{BA}=$ Business Administration

${ }^{\mathrm{b}}$ Items asked "please indicate your level of agreement with the follow statements. The following BBA core course added value to my education." A 6-point response scale was used, where $1=$ strongly disagree, $2=$ disagree, $3=$ slightly disagree, $4=$ slightly agree, $5=$ agree, $6=$ strongly agree. In addition, a "Not applicable" response option was also given, and coded as Missing.

\subsection{Can Distinct Added Education Value Business Administration Core Scales be Developed?}

As suggested earlier, based on the two more common business administration core courses of ethics and capstone business policy, a two-item "Business Administration (BA) Generic" scale was formed versus a four-item "Business Administration (BA) Unique" scale, combining the professional development strategies, Excel for business applications, business communications and integrative business applications courses. The coefficient alphas (reliability estimates) for each scale were BA Generic -.68 and BA Unique -.71. Coefficient alphas above .70 indicate good reliability estimates (Nunnally, 1978). The correlation between these two scales was $\mathrm{r}(163)=.63, p<.01$. The overlap between these scales was $(.63)^{2}=40 \%$, which indicates that there is sufficient distinctiveness between these two scales to be used separately (Stevens, 1996). Collectively these results provide support for RQ1.

\subsection{Are the Two Business Administration Core Scales Perceived to be Equal in Added Education Value?}

Given their sufficient independence, one paired-sample t-test was done to test this question. The results were that the BA Unique scale had a marginally higher perceived added education value mean (4.59 versus 4.45$)$ than the BA Generic scale, $t(164)=1.81, p<.07$. This result provides partial support for RQ2.

3.4 Are There Differences in the Correlations of the Business Administration Core Scales to BBA Satisfaction and Business School Reputation Influence?

The correlations between the two business administration core scales to BBA satisfaction and business school reputation influence are shown in Table 2. In order to test for a significant difference between correlations from the same sample, the $r$ to $z$ transformation formula (Stevens, 1996) was used. There were two significant differences found. First, the correlation of the BA Unique scale to BBA satisfaction, $r(163)=.61$, was 
significantly higher than the correlation of the BA Generic scale to BBA satisfaction $r(163)=.42, t(162)=3.55$, $p<.01$. In addition the correlation of the BA Unique scale to Business School Reputation Influence, $\mathrm{r}(163)=.39$ was significantly higher than the correlation of the BA Generic scale to Business School Reputation Influence, $r(163)=.26, t(162)=2.08, p<.05$. These results provide support for RQ3.

Table 2. Means, Standard Deviations, Reliabilities and Correlations for Study Variables and Tests for Differences

\begin{tabular}{llllllll}
\hline Variable & $\mathrm{M}^{\mathrm{a}}$ & $\mathrm{SD}$ & Alpha & 1 & 2 & 3 & 4 \\
\hline Business Administration Unique $^{\mathrm{a}}$ & $4.59^{\mathrm{c}}$ & 1.02 & .71 & $(---)$ & & & \\
Business Administration Generic $^{\mathrm{b}}$ & $4.45^{\mathrm{c}}$ & 1.28 & .68 & $\mathbf{6 3 * *}$ & $(---)$ & & \\
BBA Satisfaction $^{\text {Business School Reputation Influence }}$ & 4.74 & .81 & .78 & $\mathbf{. 6 1 * * \mathrm { d }}$ & $\mathbf{. 4 2 * * \mathrm { e }}$ & $(---))$ & \\
\hline
\end{tabular}

Note. $\mathrm{N}=165 .{ }^{* *} p<.01$. A six-point response scale was used for all the above variables, where $1=$ strongly disagree to $6=$ strongly agree. Alpha $=$ internal reliability estimates for multi-item scales, $\mathrm{NA}=$ not applicable.

${ }^{\mathrm{a}}$ Business Administration Unique $=$ Mean of 4 items/4, (BA 2101, Professional Development Strategies + BA 2104, Excel for Business Applications + BA 2196, Business Communications + BA 3103, Integrative Business Applications);

${ }^{\mathrm{b}}$ Business Administration Generic $=$ Mean of 2 items/2, (BA 3102, Business, Society and Ethics + BA 4101, Global Business Policies)

${ }^{c}$ Paired samples t-test, Business Administration Unique - Business Administration Generic, $t(164)=1.81, p<.07$, two-tailed.

${ }^{\mathrm{d}-\mathrm{e}}$ Significant difference in bolded correlations where different superscripts used, $t(162)=3.55, p<.01$.

${ }^{\mathrm{f}-\mathrm{g}}$ Significant difference in bolded correlations where different superscripts used, $t(162)=2.08, p<.05$.

\section{Discussion}

To the author's knowledge, there has been no prior research asking for business undergraduate perceptions of the "added value to their education" for business core courses. As such the results of this study should best be regarded as exploratory and promising, but in need of follow-up. Two distinct, reliable added education value BA core scales were found for the study sample: BA Unique and BA Generic. These scales represented six of the 21 business core courses required by the business school. Unfortunately, the full complement of all business core courses could not be used due to sample size limitations. The six BA courses studied here can typically not be waived, for example if coming in as a transfer student. Approximately $50 \%$ of the undergraduates transfer into the business school and many waive the other required business core courses (e.g., accounting, statistics, economics). Given the amount of missing data across these waived core courses, it was not possible to aggregate these other business core course items into potentially other distinct business core scales.

Instead, this study focused only on using the six business administration core courses. There was minimal missing data partially because of the previously mentioned non-standardized content for the four unique business administration courses. The two general business administration cores, ethics and global business policies, cannot be waived as upper level courses in the BBA. Both BA core scales were significantly positively related to degree satisfaction, which is consistent with more generalized research on student satisfaction (Alves, 2011; Ledden et al., 2007). However, the BA Unique scale had a significantly stronger relationship to degree satisfaction than the BA Generic scale. The BA Unique scale also had a stronger relationship to business school reputation influence than the BA Generic scale. Finally, the BA Unique scale had stronger perceived added education value to students then the BA Generic scale. To the curricula assessment staff at the business school, such stronger findings supported the development of these four more specialized BA core courses based on student, faculty, employer and other stakeholder needs.

The general item referent for all required core courses was perceived "added value to my education." This phrase is open to various interpretations by students. Most prior research on students' perceptions of general education value suggest that some type of "price versus quality" or functional value assessment is made (Alves, 2011). However, other interpretations of perceived value are certainly possible. For example, research on Polish business student perceptions of educational value (Dziewanowska, 2017) suggests that added value to one's education could also fit into a knowledge-related factor having epistemic value, or as a practice-related factor, e.g., as a prerequisite to getting a good job. Future research is needed to assess how students interpreted "added value to my education."

\subsection{Study Limitations and Implications for Future Assessment}

There are a number of study limitations to acknowledge. As noted earlier, only six of the 21 required business core courses could be used due to insufficient sample size when trying to work with all 21 courses. Given the 
smaller sample size for fall (versus spring) graduating seniors, the focus was only on the six business administration core courses. Future research is needed to work with all 21 business core courses using a larger sample size to compensate for the loss in subjects when trying to aggregate data across core course items to build scales. Approximately $50 \%$ of the business students transfer into the business school with credits for equivalent business core courses.

There was minimal missing data for the current sample when focusing on the six BA core courses. Both BA core scales were significantly positively related to BBA satisfaction and business school reputation influencing perceived market value to potential employers, but the BA Unique scale had a stronger relationship to both variables than the BA Generic scale. A stronger research design for inferring causality would be to collect the BA core item data at Time 1 and then match these Time 1 responses to satisfaction and reputation data collected at Time 2. However, since this was an exit survey for graduating seniors, such longitudinal data collection was not possible. The business school reputation variable was only one-item which does not allow for a reliability estimate. Different students may also have varying perceptions of what affects a student's market value to potential employers. Future research testing the relationships of added education value business core scales to other outcomes is recommended, such as student engagement (Haug, Berns Wright, \& Huckabee, 2018) or employment-related (Jackson, 2013).

Another measurement limitation is that graduating seniors were asked to remember the added educational value of business core courses, some of which they may have taken several years earlier. Given the use of self-report data, a one-factor test (Podsakoff, Mackenzie, Lee, \& Podsakoff, 2003) was carried out to assess common method bias. The results showed three factors with eigenvalues over one, with the first factor accounting for $34 \%$ of the variance. Thus, if this first factor represents common method bias, it is not an overriding limitation. Finally, respondents were generally full-time business students from a large business school based in a large urban-based, public university. The size, faculty strengths and stakeholder needs represented at this AACSB business school resulted in less typically-required required business administration core courses (e.g., professional development strategies, Excel for business applications) that may not be required at other AACSB or non-AACSB business schools. Looking at a broader range of business schools in different university settings (e.g., smaller, rural/suburban, private) and student mix, (e.g., part-time), to test the generalizability of these initial findings is recommended for future research.

\subsection{Conclusion}

Business core courses typically involve a significant component of the overall educational investment a student makes for attaining a business degree. Student perceptions for the added education value of each required core course is important to study in order to look for ways to improve that course. However, from a research perspective, it can be inefficient to work with core courses as individual items. Two promising added education value scales for future research were found: BA Generic and BA Unique. The BA Unique core scale had higher perceived added education value than the BA Generic core scale. In addition, the BA Unique scale had stronger relationships than the BA Generic scale to degree satisfaction and business school reputation affecting perceived market value to potential employers. These results supported the development of more unique required core courses based on business school stakeholder needs. Other schools should consider their stakeholders' needs to see if more unique required core courses, beyond generic, are needed. Ongoing business student curricula assessment research should include perceived added educational value of the business core curriculum, given that all business students must take it, regardless of their major, and its prominence as part of the standards for accreditation in the AACSB accreditation process (AACSB, 2013).

\section{References}

AACSB (2013). 2013 Eligibility Procedures and Accreditation Standards for Business Accreditation. Tampa, FL: AACSB.

Alves, H. (2011). The measurement of perceived value in higher education: a unidimensional Approach. The Service Industries Journal, 31(12), 1943-1960, https://doi.org/10.1080/02642069.2011.550042

Blau, G., Williams, W., Jarrell, S., \& Nash, D. (2019). Exploring common correlates of business undergraduate satisfaction with their degree program versus expected employment. Journal of Education for Business, 94(1), 31-39. https://doi.org/10.1080/08832323.2018.1502144

Hahn, W. (2018). Assurance of learning: The impact of business core course reviews on student's scores on the comprehensive business exam for both internal and external comparative purposes. Journal of Education for Business, 94(1), 40-45. https://doi.org/10.1080/08832323.2018.1502740 
Haug, J. C., Berns Wright, L., \& Huckabee, W. A. (2018). Undergraduate business students' perceptions about engagement. Journal of Education for Business, 94(2), 81-91. https://doi.org/10.1080/08832323.2018.1504738

Jackson, D. (2013). Student perceptions of the importance of employability skill provision in business undergraduate programs. Journal of Education for Business, 88, 271-279. https://doi.org/10.1080/08832323.2012.697928

Ledden, L., Kalafatis, S. P., \& Samouel, P. (2007). The relationship between personal values and perceived value of education. Journal of Business Research, 60, 965-974. https://doi.org/10.1016/j.jbusres.2007.01.021

Martell, K. (2007). Assessing student learning: Are business schools making the grade? Journal of Education for Business, 82(4), 189-195. https://doi.org/10.3200/JOEB.82.4.189-195

Meade, J. (1986). The business core curriculum: Is it time for a change? Journal of Education for Business, 62(3), 108-110. https://doi.org/10.1080/08832323.1986.10772784

National Student Satisfaction and Priorities Report (2017). Ruffalo Noel Levitz. Retrieved January 4, 2019, from http://learn.ruffalonl.com/WEB2017NationalStudentSatisfactionReport_LandingPage.html

Nelson, J., Smith, L. B., \& Hunt, C. S. (2014). The migration toward ethical decision-making as a Core course into the B-School: Instructional strategies and approaches for consideration. Journal of Education for Business, 89(1), 49-56. https://doi.org/10.1080/08832323.2012.749205

Nunnally, J. (1978). Psychometric theory (2nd ed.) New York: McGraw Hill.

Payne, S. L., Whitfield, J. M., \& Flynn, J. A. (2002). Assessing the business capstone through a method based on the SOTL and the stakeholder process. Journal of Education for Business, 78(2), 69-74. https://doi.org/10.1080/08832320209599700

Pelletier, C., Rose, J., Russell, M., Guberman, D., Das, K., Bland, J., ... Chambers, C. R. (2017). Connecting student engagement to student satisfaction: A case study at East Carolina University. Journal of Assessment and Institutional Effectiveness, 6(2), 123-141. https://doi.org/10.5325/jasseinsteffe.6.2.0123

Peterson, R. L., Berenson, M. L., Misra, R. B., \& Radosevich, D. J. (2008). An evaluation of factors regarding students' assessment of faculty in a business school. Decision Sciences Journal of Innovative Education, 6(2), 375-402. https://doi.org/10.1111/j.1540-4609.2008.00182.x

Pharr, S. W. (2000). Foundational considerations for establishing an integrated business common core curriculum. Journal of Education for Business, September/October, 20-23. https://doi.org/10.1080/08832320009599045

Pharr, S. W. (2003). Integration of the core business curriculum: Levels of involvement and support provided. Marketing Education Review, 13(1), 21-31. https://doi.org/10.1080/10528008.2003.11488808

Podsakoff, P., Mackenzie, S., Lee, J., \& Podsakoff, N. (2003). Common method biases in behavioral research: Critical review of the literature and recommended remedies, Journal of Applied Psychology, 88(5), 879-903. https://doi.org/10.1037/0021-9010.88.5.879

SPSS-PC, version 24. (2015). Statistical package for the social sciences. Chicago: IBM Corporation. SSI, 2018. Student Satisfaction Inventory. TM Retrieved May 30, 2018, from https://www.ruffalonl.com/complete-enrollment-management/student-success/studentsatisfactionassessmen $\mathrm{t} /$ student-satisfaction-inventory_

Stevens, J. (1996). Applied multivariate statistics for the social sciences (2nd ed.). Mahwah, NJ: Lawrence Erlbaum.

Yunker, P. J., \& Yunker, J. A. (2003). Are student evaluations of teaching valid? Evidence from an analytical business core course. Journal of Education for Business, July/August, 313-317. https://doi.org/10.1080/08832320309598619

\section{Copyrights}

Copyright for this article is retained by the author, with first publication rights granted to the journal.

This is an open-access article distributed under the terms and conditions of the Creative Commons Attribution license (http://creativecommons.org/licenses/by/4.0/). 